\title{
Lo que callan los corpus, lo que afirman los cuerpos
}

\author{
Elena Losada Soler, Helena González Fernández y Alicia \\ Ramos González (eds.)
}

ArCiBel, Sevilla, 2013, 200 pp. ISBN: 978-84-15335-46-7

The volume Lo que callan los corpus, lo que afirman los cuerpos collects a variety of essays that confront the way in which the female textual body is silenced, by being ignored and / or elided from the cannon, and how this is reflected in the silencing of the material, physical body. Each of the essays included herein look to excavate and reanimate the otherwise mummified corpse of women's writing. On the other hand, and in line with the second-wave feminist project of tracing women's genealogies and herstories, they seek to recover the valuable contribution of women writers to literatures past. In their prologue, the editors open with a reference to Umberto Eco's Storia della bellezza (1984) in which women's bodies are discussed as mute testaments to history, objects upon which the word is written, but who are denied any trace of subjectivity. Lo que callan los corpus, lo que afirman los cuerpos contests the mute female form and breathes life into the mute statues that represent women in history by excavating both the life and writing of a sample of oftentimes ignored or silenced women writers. As a contribution to the field of critical analysis of women's writing, this text covers a wide variety of authors, ranging across time, geography, and language, and of methodologies, from close textual analysis to pedagogical practice.

Despite the disparate subject matter, each of the essays included in this volume writes against silence, against the variety of ways in which women's voices and bodies are and have been subjected to systemic violence and horror through the robbing of voice. Through their writings, each of the authors included affirms the value of the texts, and the women who wrote them, under consideration.

Daniele Cerrato, in "Poesía femenina italiana de los siglos XIII y XIV entre silencio, lamento y rebeldía" and Mercedes Arriaga Flórez in "Somatizaciones en escritoras italianas: Enriqueta Caracciolo" both turn their gaze to Italian women's writing. Cerrato contests the heretofore widely held opinion that women were not valued and contributing members of society in the Middle Ages, and asserts that the women poets of the thirteenth and fourteenth centuries are proof of the way in which women rebelled against the systemic marginalisation of women's voices, and turned to poetry as a way of claiming a place and position within society. Far from merely imitating male poets, Cerrato argues that this early demonstration of women's participation in literature offers examples of women writing women's experience.

Arriaga Flórez considers a much later example, from the nineteenth century, and yet continues the project of reaffirming the genealogy of women writers in 
Italy. More broadly, the case of Enriqueta Caracciolo Fiorino, the unwilling nun who eventually turns her back on the convent, and who narrates her body, demonstrates the power of bodily language and the way in which the symptomatic body can reflect the body politic, in this case of the Italian nation-state.

The link between writings of the body and the nation is continued in Helena González Fernández's illuminating essay "La nación edénica y la vulnerabilidad de las mujeres en Rosalía de Castro". The application of Judith Butler's theory of vulnerability to the nineteenth century Galician writer's work is an innovative way of exploring the themes of the burgeoning Galician nation-state, women, and emigration so integral to de Castro's texts. Through a vigorous interrogation of de Castro's use of images of mourning, precarity, and loss, the construction of the Galician nation-state is distanced from the heroic, mythic, and Edenic narrative, and focuses on the role women played in its constitution.

In "Silencios de doble filo: re-presentación del cuerpo de la mujer en la poesía de Florbela Espanca, Irene Lisboa y Judith Teixeira”, Cláudia PazosAlonso considers the way in which women's bodies and writing are marginalised within the Portuguese literary canon. By engaging in the important work of shifting the focus from the uncontested figures of canonised literature to women writing from the margins, Pazos-Alonso recovers the voices and writings of three integral women poets within the literary tradition.

Alicia Ramos González's in-depth consideration of Débora Barón's biography sheds light on this author's eventual retirement from life in the public sphere to one of enclosure. In sharp contrast to the example of Enriqueta Caracciolo Fiorone, who sought freedom from the walls of the convent, Barón eventually opted to seclude herself from the turmoil of life outside of her home. For both women, however, the life of the body, the life of the mind, and the way in which writing mediates between the two, are of primary importance.

Moving from the European continent to literature of the Latin Americas, Mariola Pietrak traces the history of women's writing in the Americas in her essay "Lenguajes del cuerpo de mujer. Una mirada retrospectiva a la producción literaria en Hispanoamérica". In this consideration of the position and role of women writers within the literary production of South America, Pietrak reaffirms the notion that the absence of woman authored texts is not due to a lack of writers, but rather to an uneven publishing market which ignores, when it does not negate outright, writings by women. Continuing with the theme recurrent throughout several of the essays in this collection, the infirm body, the body that, through its refusal to be well and good, becomes disobedient, is further considered in Pietrak's essay.

The theme of infirmity is taken up yet again in Silvina A. Míguez's "Más allá de la palabra, el cuerpo: de como la creación trasciende sobre el horror y el silencio". In this instance, however, the author considers the play El vuelo inmóvil (The Still Flight) by José Rubén Pupko, in which memory, collective and indivi- 
dual, is used to bring to the fore questions about the body as a text. The play's protagonist is Frida Kahlo, and as she awaits her death she is both physically and intellectually moved through time and space, and Míguez argues that these contrasts illustrate the way in which the world is constructed through contrasts. The essay points to the way in which memory and history are both competing and mutually constructing elements that must be constantly negotiated.

The negotiation of time, of space, and of identity is differently broached in Carmen García Navarro's essay, “Rompiendo silencios mientras probamos lenguas: sobre mujeres, educación, literature y vida”. García Navarro moves away from textual and biographical analysis to consider the implications of using poetry for adult and migrant learners in the second language classroom, arguing that both reading and writing poetry can be libratory experiences for the adult learner, offering as they do forms of recognition and expression that extend beyond the day-to-day and into the intimate sphere. For students whose voices are often silenced within society, poetry serves to help express and articulate their feelings.

In the final essay in the collection, Elena Losada Soler returns to questions of women's voices and representation in "De mujer-monstruo a monstruo-víctima: Enriqueta Martí en El cielo bajo los pies de Elsa Plaza”. Losada Soler questions the way in which the so-called "Vampire of Poniente Street" was represented in both the newspapers of the time and in subsequent narratives. In her analysis of Plaza's novel, the author finds that an alternative to the dominant narrative is possible, one that interrogates the facility with which Martí was dubbed monstrous, and which elided her testimony and statements.

If previous essays in this collection work to redress the systematic omission of women's writing and voices from literary spheres, Losada Soler considers another kind of silencing, one in which news media and the voracious demand for certain types of spectatorship dictate the representation of women within the social sphere.

The differences between the essays collected in this volume serve as reminders of the extent to which the project of recovering and championing women's voices and writing is still a necessary and ongoing feminist project. By working through the various tensions between bodies subjected to the systemic violence of muting women's writing and expression and the rebellion against such constraints, the authors of Lo que callan los corpus, lo que afirman los cuerpos shed light on further writing by and about women, and the interplay between textuality and corporeality.

ANDREA RUTHVEN

andrearuthven@gmail.com 